A Research on the

Determination of Consumer

Perceptions Related to

Guerrilla Marketing

Methods: Sample of Izmir

Province

\section{Ebru Onurlubaş}

\section{Introduction}

The rapid impact of technology on human life has encouraged businesses to use new means of communication more effectively in order to influence the target audience. Nowadays, businesses have resorted to increase their competitiveness by taking advantage of new marketing methods in order to be able to stand out in the developing technology and differentiating market. Within this context, companies have started to use different marketing strategies in order to be more effective in the market and to maintain their presence and awareness in different ways. Guerilla marketing is just one of these strategies. Guerrilla marketing is an important marketing technique that small and mediumsized businesses are using with minimum marketing investments in extraordinary ways at unexpected times to attract attention of the target audience in today's increasingly competitive environment (Y1ld1z, 2016: 826). The basis of this marketing technique is to make a lasting impression on consumers with factors such as creativity and imagination with messages that are not seen before and cannot be imitated. The essential feature of guerrilla marketing is that the message is transmitted to the consumer at an unexpected time in an unexpected way. The nice issue is that a big budget is not necessary for this striking method (Altunışık et al. 2006: 180). Thus, enterprises try to create a privileged identity on the market by making their goods and services different from their competitors. The goal of guerrilla marketing, which is regarded as an important technique for businesses to adapt to ever-changing and increasingly competitive conditions, is to create a marketing management that is close to the market, dynamic, responsive to consumer needs, and empowered.

Within this context, the purpose of the study is to examine the consumer perceptions of guerrilla marketing techniques that businesses use in the marketing of their products or services. In order to achieve this aim, survey method was used as a data collection method in the research and the perceptions of consumers about guerrilla marketing techniques were analyzed.

\section{Guerrilla Marketing}

Guerrilla marketing is fundamentally guided by the guerrilla warfare and the steps taken. Like a guerrilla warrior guerrilla marketing uses different, surprising strategies while trying to attract attention (Çeltek and Bozdoğan, 2012: 4789). The guerrilla warfare, which appeared in the resistance of the Spaniards to the French Napoleon between 1807 and 1814 and was described as the weapon of the weak, was used to repel the enemy without being seen as a "soldier" tactically to the enemy (Özgül, 2008: 168). At this point, one of the marketing tactics, "Guerrilla Tactics", was first used in the mid1960s in the field of "Marketing and Advertising" in America. The Vietnamese war that had taken place in these years and the successful use of the guerrilla tactics by the people there affected the marketing industry. This victory, which seems small for the countries, actually made a great contribution to the marketing world. Companies started to increase their revenues with different marketing policies (İşler, 2016: 24). The concept of guerrilla marketing emerged when Levinson, the founder and idea leader, gave marketing lessons at the University of California at Berkeley and a group of his students who wanted to set up their own businesses asked him to recommend a book which taught "the ways to build a business without paying money" (Kaşlı et al., 2009; Arslan, 2009). As a result of his researches, Levinson, who could not find any resources for his students, answered that question by writing an article entitled "527 Ways to Market Without Much Money". Thus, the foundations of guerrilla marketing had been laid and come until today (Arslan, 2009).

The guerrilla marketing term was first used in 1984 in the book "Guerilla Marketing" written by Jay Conrad Levinson. In our day when classical marketing methods have lost its update and consumer behaviours have changed, guerrilla marketing, which is considered as an ideal marketing method for entrepreneurs with a small budget and big dreams, is based on the principle of demoralizing other players in the market and taking a place in the market, especially in small and mediumsized enterprises with small, periodic but surprising attacks (Arslan 2009: 13; Çeltek and Bozdoğan 2012: 4789; Tek, 1997: 109; Kotler, 2003a: 163; Özgül, 2008: 160 ). In order to be permanent in the market place, which was taken from demoralized competitor, efforts to increase sales, intensive advertising attacks in local areas and other legal actions are carried out (Boyd and Orville, 1990: 728). Within this context, while guerilla marketing is aiming at the highest interest in its own goods, services, and proposals, it aims the least of resources and 
costs for this endeavour. Guerrilla marketing tries to attract attention to a different side as if it were a guerrilla warrior. In doing so, the policies they apply are "different, surprising, original and entertaining". Everything comes with a small budget and can be used in every sector (Dağdaş, 2013:15).

Guerrilla marketing is a strategy aimed at going for the jugular where it is weak, without leaving a direct understanding of war against big businesses (İslamoğlu, 2013: 35). According to Kotler; the guerrilla marketing battle is to attack different areas of the enemy slowly, at intervals. The goal is to demoralize and disturb the enemy and to provide a marketing area where it can be kept all the time in the end (Kotler, 2003b). According to another definition, guerrilla marketing is the marketing activities aimed at obtaining market shares by utilizing the mistakes of competing firms instead of increasing the sales by enlarging the market (Pazarlamac1 Blog, 2017). Guerrilla marketing is based on a marketing philosophy in which creative methods that competitors cannot imitate are used and the customer can be influenced by interesting tactics. Businesses using this strategy can obtain the desired position in the mind of the customers compared to their competitors. They are beginning to make systematic plans to change customer habits and show why they need to buy their own brands as if they were entering the market for the first time (Pirtini et al., 2007). Guerrilla marketing is often associated with insidious marketing or sneaky tactics that are used without revealing them to people. Therefore, it is often expressed in many sources with ambush marketing. But according to Levinson, "you do not have to lie when you're guerrilla marketing, you do not have to be dishonest. Guerilla marketing does not mean to do anything that annoys other communities or people. Guerrilla marketing is to pursue traditional goals using unconventional tools" (Reşber, 2013: 10).

Although there are various approaches to the definition of guerrilla marketing, the source of the differences in all these definitions is that guerrilla marketing looks very different at first glance. All these different definitions characterize the founding features of guerrilla marketing. These are; It is extraordinary, surprising, original / creative, provocative / arrogant, economic / cost effective, flexible, unusual / typical, funny, brilliant and contagious (Nufer, 2011: 32; Schulte, 2007: 3 Resver, 2013: 12-13).

Guerrilla marketing was initially used only for small firms to compete against big companies better. Later, it became a low cost marketing strategy, so not only SMEs but also strong companies started to use guerrilla marketing as a marketing strategy (Kaşlı et al., 2009). The guerrilla marketing approach, which started to attract the attention of consumers with its striking examples in a short time, showed that marketing is not just advertising made with media tools and thanks to creative ideas marketing which can be done anywhere and anytime. This approach, which moves with the principle of facing potential customers unexpectedly almost everywhere such as avenues, streets, public transportation vehicles, pavements and stops, is thought to be remarkable and catchy (Çeltek and Bozdoğan, 2012).

\subsection{The Features that Guerrilla Marketing must have}

Some basic features are needed to make marketing activities and achieve success in guerrilla marketing. These are;

- having a marketing plan

- understanding the importance of following

- knowing the responsibility of undertaking a plan

- acting according to the guerrilla marketing calendar, promoting the company by participating in events such as trade fairs, seminars, conferences, etc., sending direct postcards, preparing a website for free information, subscribing to forums and organizing e-mail campaigns (Pazarlama Makaleleri,2017).

For a marketing strategy to be guerrilla marketing there must be basic features such as a simple and viable marketing plan, a good timing, a well-defined target market, a faithful and energetic entrepreneur, a wellchosen and purposefully targeted marketing weapon, imagination and patience (Arslan, 2009: 14). It is also necessary for a business to adopt an attitude that is willing, curious, self-confident, realistic, objective, imaginative and ready to compete in order to conduct guerrilla marketing. In an environment where everyone is struggling to gain a privileged position in the mind of the customer, the ones who find and implement the most intelligent and creative solutions become successful (Chief, 2008: 31).

\subsection{The Process Needed to Be Followed in Guerrilla Marketing}

Levinson and Rubin (1996) have described the process that businesses need to follow in order to implement guerrilla marketing in five main stages. We can list the guerrilla marketing process and the activities to be carried out at each stage of the process as follows;

- Creating a broad database: Businesses must first create a database that is as detailed and accurate as possible about their internal and external environment. This database should contain detailed information about employees, customers, market situation and competitors, and should be guiding in shaping marketing efforts.

- Conducting SWOT (strengths, weaknesses, opportunities threats) analysis: The business should 
conduct a SWOT analysis of itself and the market in which it operates by taking the potential threats and opportunities into account. During this analysis, the advantages of the business different from its competitors should be determined, and while the marketing strategies are being developed, the competitive advantages of the business should be considered as much as possible. Guerrillas, who are practitioners of guerrilla marketing in the direction of this data, are attempting to gather the information necessary to achieve a strategic alignment between opportunities outside the enterprise and the superiority of the business.

- The selection of the appropriate marketing weapon according to the results of the SWOT analysis: The business should choose a marketing weapon that suits its superiority once it determines the superior feature that it has. While choosing this appropriate weapon, it should focus on the differences of its products or services from the competitors' and the goals that will make the business more profitable by using the strongest side of that business.

- Preparing a marketing calendar: A market-oriented guerrilla marketing calendar should be created and kept as faithful as possible. While preparing this calendar, it is necessary to use all the marketing weapons in a coordinated manner and to be prepared at all times against the counterattack that may arise from the opponent.

- Passing on counter attacks: This phase is about the answers to the reactions of the opponents when guerrilla marketing calendar is applied. The results of the attacks made at this stage should constantly be monitored so that the reactions that are to be challenged against the opponents are passed without delay.

\section{Examples of Guerrilla Marketing in the World}

McDonald's made an interesting surprise in the hot weather with the Ice Coupon project in Brazil. McDonald's amazed visitors with an ice cold surprise with its project held in Rio de Janeiro. The campaign "24 Gifts in 24 Cities in 24 Hours", which was carried out basing on the brand's slogan "I'm lovin' it", and guerrilla marketing project in this context attracted attention with its creative concept. For the project, a vending machine that produces ice molds was placed on a busy street near the sea. In a short time, those who notice the vending machine met with the duties given to them for a delicious reward when they pushed the buttons of the machine, and learned that those who perform their duties like taking a selfie, and dancing were rewarded. The award is an Ice Coupon. The lucky winners had to go to the nearest McDonald's restaurant to use the coupons.
Another guerrilla marketing example is that Nescafe had invited people waiting in traffic lights to socialize with his guerrilla marketing project in Berlin. Nescafe invited the users who became more dependent on the internet and their phones day by day, made an interesting project in the streets of Berlin. The brand, which placed two coffee machines in the traffic lights, made a special surprise to the people waiting at traffic lights with the "press together" button. Thanks to the machines that rewarded individuals with coffee when they were pressed simultaneously, Nescafe had reached a lot of people who had been shaking hands, greeting each other, smiling and establishing a short dialogue in the middle of the road. The brand had gained appreciation by creating "instant communication" between people with this work named "Instant Connections" (Dijital Ajanslar, 2017).

When other guerrilla examples are examined, the example of guerrilla marketing which was applied by fast food brand McDonald's by using a pedestrian crossing as an alternative medium is almost the definition of guerrilla marketing. The creative minds, bored by using conventional media, had found precisely a guerrilla idea and had integrated a product of their brand to a pedestrian crossing. The cost of this tremendous example to the firm had been very little. Another guerrilla marketing asked the question "Do you have the courage to get on this elevator?" In this guerrilla marketing case, which had been conducted by a parascending school operating in Europe, the on-wall advertising which was applied to an elevator of a high-rise building caused fearful moments for the people getting on that elevator. This idea of on-wall advertising to an elevator was a great guerrilla example for a brand name to express itself. It had become a very successful application because it excited people and also led them to parachute jumping. The lifeless mannequin in the thief appearance is another kind of guerrilla contact which is carried out by a leading insurance company in Turkey. It can be taught as a lesson in schools. The firm conveys the idea of insuring individuals' home and workplace against thieves with the message "Before the thieves come to you, come to ..... insurance". This creative guerrilla marketing idea which puts a lifeless mannequin in the appearance of a thief on the balcony of a building located in Istanbul Beşiktaş attracted considerable attention and created a tremendous impression (Avansas Blog, 2017).

\subsection{Guerilla Marketing Examples and Images}

In the visuals, it is seen how brands work with guerilla marketing to influence consumers. 


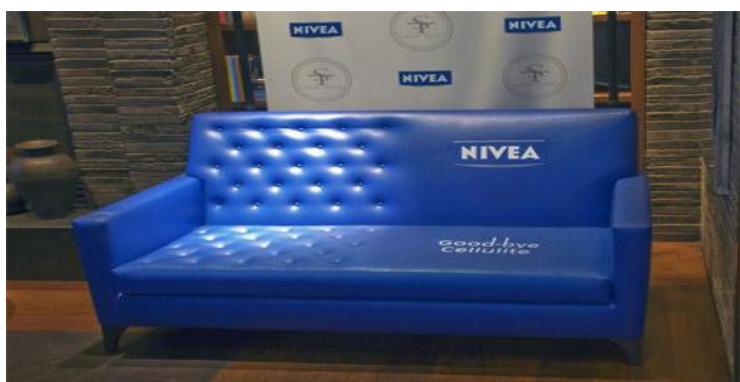

Figure 1. Nivea; If you have a smooth skin, sit on the side of Nivea

Source:http://www.aktifgirisimci.com/para-kazanmasanati/gerilla-pazarlama-ornekleri

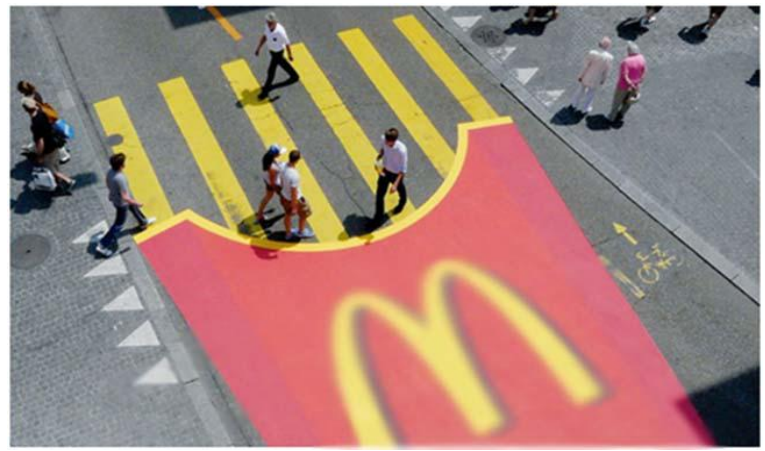

Figure 2. McDonald's Pedestrian Crossing

Source:http://blog.avansas.com/pazarlamacilarin-keskebiz-yapsaydik-dedigi-5-mukemmel-gerilla-pazarlamaornegi

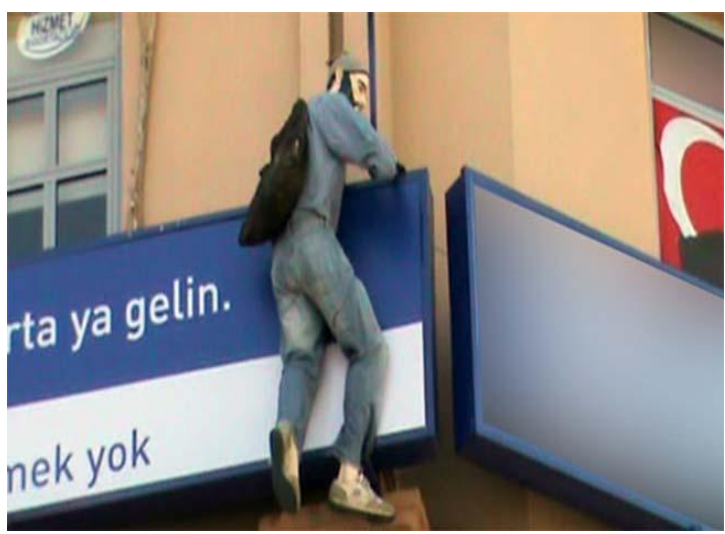

Figure 3. Lifeless mannequin in the appearance of a thief on the balcony of a building located in Istanbul Beşiktas for an insurance company

Source:http://blog.avansas.com/pazarlamacilarin-keskebiz-yapsaydik-dedigi-5-mukemmel-gerilla-pazarlamaornegi

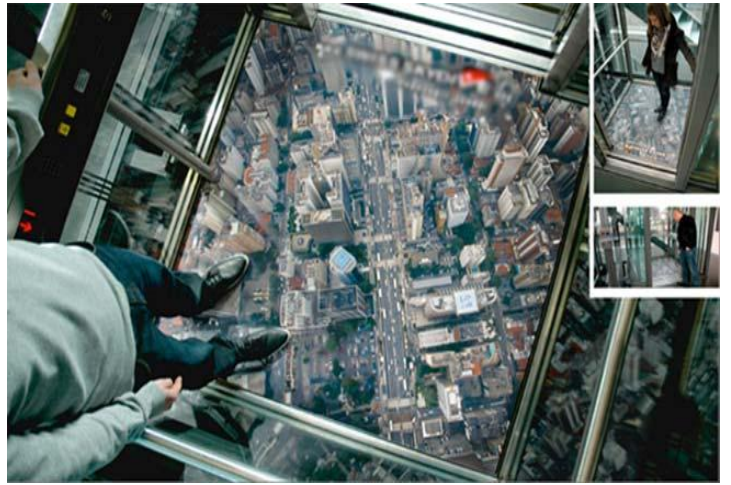

Figure 4. The on-wall advertising applied to an elevator of a high-rise building conducted by a parascending school operating in Europe

Source:http://blog.avansas.com/pazarlamacilarin-keskebiz-yapsaydik-dedigi-5-mukemmel-gerilla-pazarlamaornegi

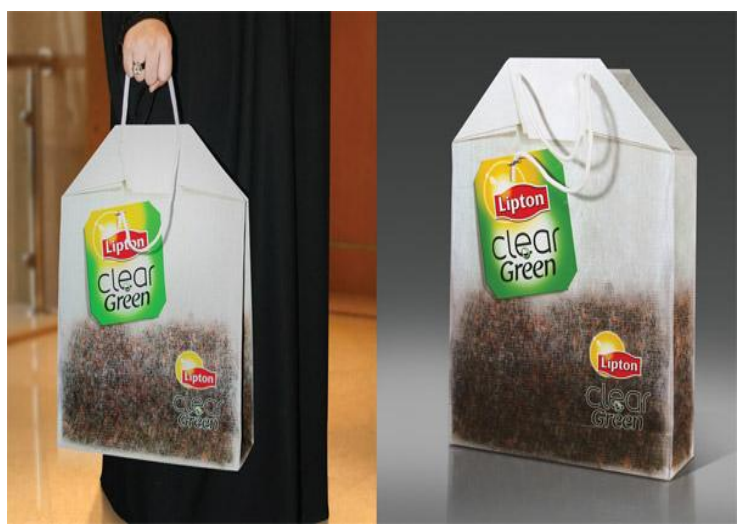

Figure 5. Lipton Tea

Source:http://www.aktifgirisimci.com/para-kazanmasanati/gerilla-pazarlama-ornekleri

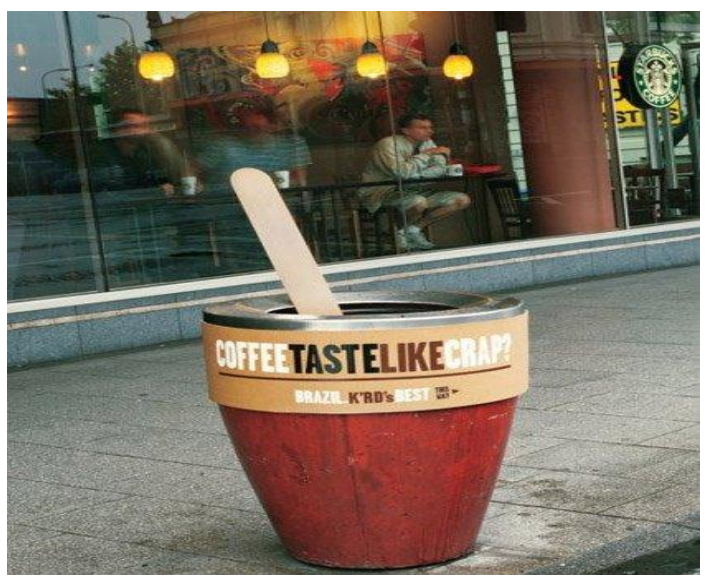

Figure 6. Brazil Coffee Company

Source:https://blogof.francescomugnai.com/2009/11/the -80-best-guerrilla-marketing-ideas-ive-ever-seen/ 


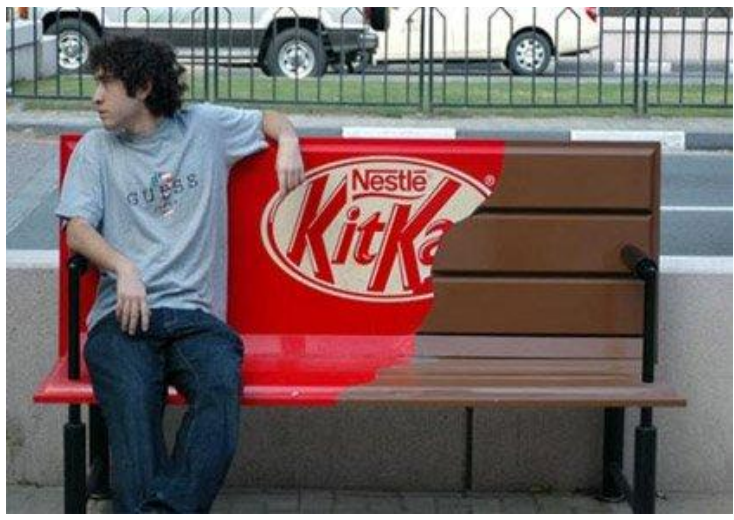

Figure 7. KitKat Chocolate

Source:https://blogof.francescomugnai.com/2009/11/the -80-best-guerrilla-marketing-ideas-ive-ever-seen/

\section{Methodology}

\subsection{Sampling and Measurement Tools}

The data gathered from 384 persons in İzmir province in 2016 is the target population of the study. The population of Izmir Province in 2016 is 4.223 .545 (Tuik, 2016).

The sample size has been determined with the help of the equation below ( Bas, 2008):

$$
n=\frac{N * t^{2} * p^{*} q}{d^{2} *(N-1)+t^{2} * p^{*} q}
$$

$\mathrm{n}$; Number of the individuals that are to take part in the sample, N; 4.223.545,

p; Probability of occurrence $(0,50)$,

q; Probability of non-occurrence $(0,50)$,

t; Standard normal distribution value $(1,96)$,

d; Sampling error $(0,05)$

After the calculation, the sample volume was determined as 384 within the $95 \%$ confidence interval and 0.05 margin of error. The survey, which was distributed to 384 people in 2016, was randomly given to consumers.

\subsection{Data Collection and Analysis}

The data obtained from the questionnaires distributed to consumers in İzmir in 2016 were analyzed using SPSS 21 statistical package program. The data collection form consists of two parts. In the first part, there are questions about the demographic characteristics of the participants and in the second part, there are 19 statements regarding the consumer perception about the guerrilla marketing methods of the enterprises. The questionnaire used in the research consists of the questionnaires prepared from the previous studies (Memişoğlu, 2014; Yıldız, 2016) and the literature given in the bibliography. Also, the questionnaire was developed by adapting 19 measurement questions, because they are relevant to the scope of the research. The questionnaire participants responded according to the Likert scale. An exploratory factor analysis was applied to the Scale of Consumer Perception on Guerrilla Marketing Methods (SCPGMM). After the exploratory factor analysis, three dimensions were presented. The most important factor was determined as "Extraordinary". Then, the KolmogorovSmirnov Test was applied to the sub-dimensions of SCPGMM and it was determined that the distribution was not normal. The variations of the sub-dimensions of SCPGMM according to the demographic characteristics of consumers were revealed by Mann Whitney U and Kruskal Wallis tests which are non-parametric tests.

\section{Research Findings}

Table 1: Demographics of the Consumers Frequency (f), Percent(\%)

\begin{tabular}{|c|c|c|c|c|c|}
\hline Gender & (f) & (\%) & Age & (f) & (\%) \\
\hline Male & 193 & 50,3 & $25-34$ & 82 & 21,4 \\
\hline Female & 191 & 49,7 & $35-44$ & 95 & 24,7 \\
\hline Total & 384 & 100,0 & $45-54$ & 91 & 23,7 \\
\hline Profession & (f) & $(\%)$ & $55-65$ & 69 & 18,0 \\
\hline Housewives & 37 & 9,6 & $\begin{array}{c}66 \text { and } \\
\text { over }\end{array}$ & 47 & 12,2 \\
\hline Worker & 85 & 22,1 & Total & 384 & 100,0 \\
\hline Civil Servants & 115 & 29,9 & $\begin{array}{l}\text { Monthly } \\
\text { incomes }\end{array}$ & (f) & (\%) \\
\hline Self-Employed & 59 & 15,4 & $\begin{array}{c}1000 \text { and } \\
\text { below }\end{array}$ & 34 & 8,9 \\
\hline $\begin{array}{l}\text { Private Sector } \\
\text { Employee }\end{array}$ & 88 & 22,9 & $1001-1500$ & 38 & 9,9 \\
\hline Total & 384 & 100,0 & $1501-2500$ & 52 & 13,5 \\
\hline Marital status & (f) & $(\%)$ & $2501-3500$ & 89 & 23,2 \\
\hline Married & 200 & 52,1 & $3501-4500$ & 92 & 24,0 \\
\hline Single & 166 & 43,2 & $\begin{array}{c}4501 \text { and } \\
\text { over }\end{array}$ & 79 & 20,6 \\
\hline Divorced & 18 & 4,7 & Total & 384 & 100,0 \\
\hline Total & 384 & 100,0 & & & \\
\hline $\begin{array}{l}\text { Educational } \\
\text { status }\end{array}$ & (f) & (\%) & & & \\
\hline $\begin{array}{l}\text { Elementary } \\
\text { School }\end{array}$ & 7 & 1,8 & & & \\
\hline $\begin{array}{l}\text { High School } \\
\text { Degree }\end{array}$ & 42 & 10,9 & & & \\
\hline $\begin{array}{l}\text { Vocational } \\
\text { School Degree }\end{array}$ & 122 & 31,8 & & & \\
\hline $\begin{array}{l}\text { Bachelor's } \\
\text { Degree }\end{array}$ & 167 & 43,5 & & & \\
\hline Master's Degree & 46 & 12,0 & & & \\
\hline Total & 384 & 100,0 & & & \\
\hline
\end{tabular}

$49,7 \%$ of the participants were women, and $50,3 \%$ were men. When the distributions according to age groups were examined, it was seen that $21,4 \%$ of the 
participants were in the age group of 25 - 34, 24,7\% were $35-44,23,7 \%$ were $45-54,18,0 \%$ were $55-65$ and $12,2 \%$ of them were 66 and over. 52,1\% of the consumers were married, $43,2 \%$ were single, and $4,7 \%$ were divorced.

When the monthly average income of families was examined, it was seen that $8,9 \%$ of them had an income of $1000 \mathrm{TL}$ and below and 9,9\% was between 1001-1500TL, 13,5\% was between 1501-2500TL, 23,2\% was between 2501-3500TL and 24\% was between 3501$4500 \mathrm{TL}, 20,6 \%$ had an income of $4501 \mathrm{TL}$ and above. When the persons participating in the survey were examined according to occupation; it had been determined that $9,6 \%$ were housewives, $22,1 \%$ were workers, $29,9 \%$ were civil servants, $15,4 \%$ were selfemployed and 22,9\% were private sector employees.

According to the evaluation results of education data, $1,8 \%$ of the participants were elementary school graduates, $10,9 \%$ had high school degree, $31,8 \%$ had vocational school degree, 43,5\% had bachelor's degree, $12,0 \%$ had master's degree.

Table 2: KMO and Barlett Results of the Scale of Consumer Perception on Guerrilla Marketing Methods (SCPGMM)

\begin{tabular}{|l|l|l|}
\hline \multicolumn{2}{|l|}{ Kasiser Meyer Olkin (KMO) } & $\mathbf{0 , 8 7 2}$ \\
\hline \multirow{4}{*}{$\begin{array}{l}\text { Bartlett Sphericity } \\
\text { Testi }\end{array}$} & $\begin{array}{c}\chi^{2} \text { (Chi-Square) } \\
\text { Ff (Degrees of }\end{array}$ & 2,51903 \\
\cline { 2 - 3 } & Preedom) & 105 \\
\cline { 2 - 3 } & Probability) & $\mathbf{0 , 0 0 0} *$ \\
\hline
\end{tabular}

If the value found in the KMO test is below 0,50 , it is unacceptable, 0,50 is weak, 0,60 is moderate, 0,70 is good, 0,80 is very good, 0,90 is excellent (Sharma 1996). The KMO value of the study is very good at 0.87 . As a result of the Bartlett Sphericity test, $\chi^{2}: 2,51903$, Sd:105 $\mathrm{P}<0,05$. For this reason, the data set is suitable for factor analysis.

Table 3: Variance Description of the Scale of Consumer Perception on Guerrilla Marketing Methods (SCPGMM)

\begin{tabular}{|c|c|c|c|c|c|c|}
\hline \multirow[b]{2}{*}{ Factor } & \multicolumn{3}{|c|}{ Initial Eigenvalues } & \multicolumn{3}{|c|}{$\begin{array}{r}\text { Extraction Sums of Squared Loadings } \\
\text { (Varimax) }\end{array}$} \\
\hline & Total & $\begin{array}{c}\text { Explained } \\
\text { Variance } \\
(\%)\end{array}$ & Cumulative(\%) & Total & $\begin{array}{r}\text { Explained } \\
\text { Variance } \\
(\%) \\
\end{array}$ & Cumulative( $\%$ ) \\
\hline l & 5,403 & 36,017 & 36,017 & 5,013 & 33,420 & 33,420 \\
\hline 2 & 2,395 & 15,964 & 51,981 & 2,040 & 13,599 & 47,019 \\
\hline 3 & 1,017 & 6,780 & 58,761 & 1,761 & 11,742 & 58,761 \\
\hline
\end{tabular}

In the results of varimax rotation, the items are collected under a total of 3 factors. These factors account for $58.761 \%$ of the total variance. The first factor accounts for $33,420 \%$ of the total variance, the second factor for $13,599 \%$ and the third factor for $11,742 \%$.
Table 4: Exploratory Factor and Reliability Analyses Results of the Scale of Consumer Perception on Guerrilla Marketing Methods (SCPGMM)

\begin{tabular}{|c|c|c|c|c|}
\hline Factor & Code & Statements & $\begin{array}{c}\text { Factor } \\
\text { load } \\
\text { values }\end{array}$ & $\begin{array}{c}\text { Cronbach's } \\
\text { Alpha }\end{array}$ \\
\hline \multirow{8}{*}{$\begin{array}{l}\text { Factor } \\
1\end{array}$} & S1s1 & $\begin{array}{l}\text { It offers } \\
\text { innovations based } \\
\text { on imagination. }\end{array}$ & ,783 & \multirow{8}{*}{,922 } \\
\hline & s1s10 & $\begin{array}{l}\text { It differs from } \\
\text { conventional } \\
\text { marketing } \\
\text { methods. }\end{array}$ & ,815 & \\
\hline & s1s8 & $\begin{array}{l}\text { It is more fun than } \\
\text { the other } \\
\text { marketing } \\
\text { methods. }\end{array}$ & ,823 & \\
\hline & s1s6 & $\begin{array}{l}\text { It uses creative } \\
\text { techniques and } \\
\text { methods. }\end{array}$ & ,885 & \\
\hline & s1s3 & $\begin{array}{l}\text { It introduces new } \\
\text { products and } \\
\text { services with their } \\
\text { different } \\
\text { characteristics } \\
\text { compared to its } \\
\text { peers. }\end{array}$ & ,787 & \\
\hline & s1s13 & $\begin{array}{l}\text { It uses different } \\
\text { advertising } \\
\text { techniques. }\end{array}$ & ,745 & \\
\hline & s1s14 & $\begin{array}{l}\text { It changes } \\
\text { consumer's } \\
\text { conventional } \\
\text { purchasing } \\
\text { tendencies. }\end{array}$ & ,773 & \\
\hline & s1s15 & $\begin{array}{l}\text { Unusual } \\
\text { promotional } \\
\text { techniques brand } \\
\text { the products and } \\
\text { services offered. }\end{array}$ & ,662 & \\
\hline \multirow{4}{*}{$\begin{array}{l}\text { Factor } \\
2\end{array}$} & s1s4 & $\begin{array}{l}\text { With } \\
\text { unconventional } \\
\text { tools, It is } \\
\text { imbedded in the } \\
\text { consumer's sub- } \\
\text { conscious }\end{array}$ & ,547 & \multirow{4}{*}{.640} \\
\hline & S1s7 & It's exciting & ,649 & \\
\hline & S1s9 & $\begin{array}{l}\text { It contains } \\
\text { interesting } \\
\text { messages }\end{array}$ & ,676 & \\
\hline & S1s2 & $\begin{array}{l}\text { It may occur } \\
\text { unexpectedly. }\end{array}$ & ,710 & \\
\hline \multirow{3}{*}{$\begin{array}{l}\text { Factor } \\
3\end{array}$} & S1s11 & $\begin{array}{l}\text { Its relationship } \\
\text { with the consumer } \\
\text { in marketing is } \\
\text { good. }\end{array}$ & ,679 & \multirow{3}{*}{,650 } \\
\hline & $\mathrm{S} 1 \mathrm{~s} 12$ & $\begin{array}{l}\text { Its marketing } \\
\text { communication is } \\
\text { strong. }\end{array}$ & ,814 & \\
\hline & S1s5 & $\begin{array}{l}\text { It establishes an } \\
\text { emotional } \\
\text { connection with } \\
\text { the consumer. }\end{array}$ & ,638 & \\
\hline
\end{tabular}


In the guerrilla marketing evaluation, 19 variables, which were highly related to each other, were reduced by factor analysis and are distributed to 3 factors. It was seen that the 19th, 12th, 10th, 5th and 8th factors were below 0.400 and all others' factorial loads were above 0.400 . In the direction of this result, 19th, 12th, 10th, 5th, 8th items were removed from the scale and factor analysis was applied again. Factors that were effective as a result of coverage of item 15 were collected in 3 groups. 'Extraordinary' had been identified as the most important factor. The second important factor was 'Interesting and surprising', and the final one was 'Communication' factor. For the first factor, the factor loadings ranged from 0.885 to 0.622 ; for the second factor, they ranged from 0.710 to 0.547 and for the third factor, they ranged from 0.814 to 0.638 .

Sipahi, Yurtkoru and Çinko stated that the Cronbach Alpha reliability coefficient should be above 0.70 . However, it is also stated that when the number of questions in the scale is few, the lower limit can be accepted as 0.60 or more, or it can be withdrawn up to 0.50 in some studies (Öztürk and Babacan, 2012; Sipahi et al., 2008; Altunışık et al., 2010). The Cronbach Alpha value was found 0.92 for Factor 1, 0.64 for Factor 2, 0.65 for Factor 3.

Table 5: Kolmogorov-Smirnov Test Results Regarding the Sub-dimensions of the Scale of Consumer Perception on Guerrilla Marketing Methods (SCPGMM)

\begin{tabular}{|l|l|r|r|r|}
\hline \multicolumn{5}{|c|}{ One-Sample Kolmogorov-Smirnov Test } \\
\hline \multirow{2}{|l|}{} & \multicolumn{1}{|c|}{ F1 } & \multicolumn{1}{|c|}{ F2 } & \multicolumn{1}{c|}{ F3 } \\
\hline N & 384 & 384 & 384 \\
\hline \multirow{2}{*}{$\begin{array}{l}\text { Normal } \\
\text { Parameters }\end{array}$} & Mean & 25,1849 & 14,3177 & 11,1641 \\
\cline { 2 - 5 } & $\begin{array}{l}\text { Std. } \\
\text { Deviation }\end{array}$ & 6,93609 & 2,82808 & 2,30147 \\
\hline \multirow{3}{*}{$\begin{array}{l}\text { Most Extreme } \\
\text { Differences }\end{array}$} & Absolute &, 158 &, 127 &, 134 \\
\cline { 2 - 6 } & Positive &, 109 &, 082 &, 088 \\
\cline { 2 - 6 } & Negative &,- 158 &,- 127 &,- 134 \\
\hline Kolmogorov-Smirnov Z & 3,088 & 2,492 & 2,625 \\
\hline Asymp. Sig. (2-tailed) &, 000 &, 000 &, 000 \\
\hline
\end{tabular}

$\mathrm{H} 0=$ The sub-dimensions of the SCPGMM have normal distribution.

H1 = The sub-dimensions of the SCPGMM do not have normal distribution.

As shown in Table 5, the hypothesis $\mathrm{H} 0$ is rejected because $\mathrm{p}<0,05$. In other words, the subdimensions of the SCPGMM do not have normal distribution.
Mann-Whitney U and Kruskal Wallis nonparametric tests were applied to the three sub-dimensions of the SCPGMM according to gender, age, marital status, education, occupation and income.

Table 6: Variations Test Results of the Subdimensions of the SCPGMM according to Consumer Demographics (Variables)

\begin{tabular}{|c|c|c|c|}
\hline Variables & $\begin{array}{l}\text { Sub- } \\
\text { Dimension }\end{array}$ & Test Type & $\mathrm{p}$ \\
\hline \multirow[t]{3}{*}{ Gender } & F1 & $\begin{array}{l}\text { Mann } \\
\text { Whitney U }\end{array}$ & $0,006 *$ \\
\hline & F2 & $\begin{array}{l}\text { Mann } \\
\text { Whitney U }\end{array}$ & 0,205 \\
\hline & F3 & $\begin{array}{l}\text { Mann } \\
\text { Whitney U }\end{array}$ & $0,012 *$ \\
\hline \multirow[t]{3}{*}{ Age } & F1 & $\begin{array}{l}\text { Kruskal } \\
\text { Wallis }\end{array}$ & $0,000^{*}$ \\
\hline & F2 & $\begin{array}{l}\text { Kruskal } \\
\text { Wallis }\end{array}$ & 0,412 \\
\hline & F3 & $\begin{array}{l}\text { Kruskal } \\
\text { Wallis }\end{array}$ & 0,375 \\
\hline \multirow[t]{3}{*}{ Marital Status } & F1 & $\begin{array}{l}\text { Kruskal } \\
\text { Wallis }\end{array}$ & $0,004 *$ \\
\hline & F2 & $\begin{array}{l}\text { Kruskal } \\
\text { Wallis }\end{array}$ & 0,170 \\
\hline & F3 & $\begin{array}{l}\text { Kruskal } \\
\text { Wallis }\end{array}$ & $0,002^{*}$ \\
\hline \multirow[t]{3}{*}{$\begin{array}{l}\text { Educational } \\
\text { Status }\end{array}$} & F1 & $\begin{array}{l}\text { Kruskal } \\
\text { Wallis }\end{array}$ & $0,003^{*}$ \\
\hline & F2 & $\begin{array}{l}\text { Kruskal } \\
\text { Wallis }\end{array}$ & $0,008^{*}$ \\
\hline & F3 & $\begin{array}{l}\text { Kruskal } \\
\text { Wallis }\end{array}$ & 0,380 \\
\hline \multirow[t]{3}{*}{ Profession } & F1 & $\begin{array}{l}\text { Kruskal } \\
\text { Wallis }\end{array}$ & 0,060 \\
\hline & F2 & $\begin{array}{l}\text { Kruskal } \\
\text { Wallis }\end{array}$ & 0,307 \\
\hline & F3 & $\begin{array}{l}\text { Kruskal } \\
\text { Wallis }\end{array}$ & 0,154 \\
\hline \multirow{3}{*}{$\begin{array}{l}\text { Monthly } \\
\text { Income of the } \\
\text { Family }\end{array}$} & F1 & $\begin{array}{l}\text { Kruskal } \\
\text { Wallis }\end{array}$ & 0,054 \\
\hline & F2 & $\begin{array}{l}\text { Kruskal } \\
\text { Wallis }\end{array}$ & 0,067 \\
\hline & F3 & $\begin{array}{l}\text { Kruskal } \\
\text { Wallis }\end{array}$ & 0,072 \\
\hline
\end{tabular}

* $\mathrm{p}<0,05$; Represents the differences among the subdimensions of Scpgmm scale

In table 6, according to the Mann Whitney U test, it has been determined that Extraordinary (F1) and Communication (F3) sub-dimension varies according to gender. In the Extraordinary sub-dimension, the average of women $(208,01)$ is found to be higher than that of men $(177,16)$. When the averages of Communication subdimension are examined, it is found that the average of women $(206,73)$ is higher than that of men $(178,41)$. 
Among the sub-dimensions of SCPGMM, 'Extraordinary' sub-dimension varies according to the age. The average of the age group between 55-65 years $(235,62)$ has been found to be higher than the other age groups. When the marital status is examined, it is determined that the averages of 'extraordinary' and 'communication' sub-dimensions vary. It is seen that 'extraordinary' sub-dimension of the married $(210,60)$ is higher than that of the single $(173,87)$ and divorced $(163,17)$, and the averages of the 'communication' subdimension are also higher for the married $(200,20)$ and lower for the single $(173,81)$ and the divorced $(157,42)$. It appears that the educational status varies according to the sub-dimensions 'extraordinary' and 'interesting and surprising'. It has been found that the averages of 'extraordinary' sub-dimension $(209,69)$ and the 'interesting and surprising' sub-dimension $(203,03)$ of the persons with a master's degree are higher than the others.

\section{Conclusion}

The fact that the communication and information technologies evolving with globalization is rapidly influencing human life has caused changes in consumption patterns and lifestyles. Enterprises that want to keep up with these consumption patterns have had to look for different holding efforts to be able to take place in the market. Especially, due to the fact that small businesses have limited budgets for their marketing activities, they have been looking for marketing strategies that will create competitive advantages without forcing their budgets. One of these strategies is guerrilla marketing.

Guerrilla marketing is a marketing method that enables low-budget brands to place their products in consumer consciousness by creating sensations that emerge in unexpected places and times with creative, extraordinary, exciting and surprising tactics. Guerrilla marketing was initially applied to small businesses due to its low cost, but later on, it became used as a marketing strategy in large enterprises because of its low cost and attractiveness. In guerrilla marketing, businesses should act as a guerrilla warrior. In other words, when trying to attract attention to another place as a guerrilla warrior, they should use strategies that can be used in unexpected places at an exciting, interesting, different, surprising and creative time. Creative ideas used in guerrilla marketing techniques will appeal to consumers and they will share their experiences and photographs or videos on the social media. Thus, the brand will also reach people such as a virus via internet and the popularity will increase.

In the study conducted with 384 people in Izmir province, due to the exploratory factor analysis performed on the Scale of Consumer Perception on Guerrilla Marketing Methods; 3 sub-dimensions have been identified: Factor 1 is "extraordinary", Factor 2 is "interesting and surprising", Factor 3 is "communication".

Factor 1 Extraordinary: Consumers see guerrilla marketing techniques that are more creative as an unconventional marketing method whixh uses imaginative, fun, creative techniques by standing out amongst other traditional marketing methods, television and radio channels, billboards, newspapers, and magazines.

Factor 2 Interesting and surprising: The guerrilla marketing method draws the attention of consumers to a great extent by using unconventional tools, and various brands are imbedded in consumers' subconscious, thus it is changing the consumption habits at a low cost. Brands unexpectedly and suddenly come out with different methods and the consumer is surprised and excited. For example; Mc Donald's use of his own brand as a pedestrian crossing had been used in Europe as an intriguing and remarkable guerrilla marketing method.

Factor 3 Communication: Consumers think that the relationship and communication with the customer in guerrilla marketing techniques is better, and that it even creates an emotional bond.

When the test results of the SCPGMM subdimensions according to the demographic characteristics of the consumers are examined, it has been found that Extraordinary (F1) sub-dimension varies according to gender, age, education and marital status; Interesting and surprising (F2) sub-dimension varies according to education; and Communication (F3) sub-dimension varies according to gender and marital status.

Women find guerrilla marketing method more extraordinary than men and think that communication is better in this marketing technique. As the average age increases, consumers think that the guerrilla marketing method is more extraordinary. Married people find guerrilla marketing method more extraordinary than single and divorced people. As the educational status increases, consumers think that the guerrilla marketing method is extraordinary and interesting and surprising.

The results obtained from this study may lead the way for those who are considering to do academic work in this area. This study also reveals the consumers' perception about the guerrilla marketing method and guides the businesses that are considering using lowbudget guerrilla marketing techniques instead of using traditional marketing method and casts light on establishing their policies. 


\section{REFERENCES}

Aktif Girișimci (2013). Para Kazanma Sanatı: Gerilla Pazarlama Örnekleri, http://www.aktifgirisimci.com/para-kazanmasanati/gerilla-pazarlama-ornekleri

Altunışık, R. Özdemir, Ş. Torlak, Ö. (2006). Pazarlamaya Giriş, Sakarya Kitabevi, -III. Basım, Sakarya.

Altunışık R, Coşkun R, Bayraktaroğlu S, Yıldırım E. (2010). Sosyal bilimlerde araştırma yöntemleri. Sakarya: Sakarya Yayıncılık; 2010.

Arslan, S. (2009). Turizm Sektöründe Alternatif Bir Pazarlama Stratejisi Olarak Gerilla Pazarlamasının Kullanılması: Konaklama İşletmeleri Üzerinde Bir Araştırma. Yayınlanmamış Yüksek Lisans Tezi, Ankara: Gazi Üniversitesi Eğitim Bilimleri Enstitüsü Turizm İşletmeciliği Eğitimi Anabilim Dalı.

Avansas Blog (2014). Pazarlamacıların Keşke Biz Yapsaydık Dediği 5 Mükemmel Gerilla Pazarlama Örneği, http://blog.avansas.com/pazarlamacilarinkeske-biz-yapsaydik-dedigi-5-mukemmelgerilla-pazarlama-ornegi.

Baş, T. (2008). Gerilla Kobiler için Stratejiler, Optimist Yayın Dağıtım, İstanbul Haziran 2008.

Boyd, H. W., Orv1lle, C. W. (1990). Marketing Management. Boston: Irwin.

Çeltek, E., Bozdoğan, M. (2012). Alternatif Pazarlama İletişimi Aracı Olarak Gerilla Pazarlama: Uygulanmış Gerilla Pazarlama Reklam Örneklerinin İncelenmesi ve Turizm Sektörü İçin Model Önerileri, Journal of Yasar University 2012 28(7) s.4788-4812.

Dağdaş, G. (2013). İşletmelerde Retro Pazarlama Uygulamalarının Müşteri Bağlılığına Etkileri Üzerine Bir Araştırma. Yayınlanmamış Yüksek Lisans Tezi, Konya: Selçuk Üniversitesi SBE.

Dijital Ajanslar (2017). McDonald's: Serinleten Proje Ice Coupon, http://www.dijitalajanslar.com/mcdonaldsserinleten-proje-ice-coupon/.
İslamoğlu, H. A. (2013). Pazarlama Yönetimi, İstanbul.

İşler, Ü. (2016). Gerilla Pazarlama ve Uygulamaları. Yayımlanmamış Yüksek Lisans Tezi. Okan Üniversitesi Sosyal Bilimler Enstitüsü, İstanbul

Kaşl1, M., İlban, M. O., Şahin, B. (2009). Modern Pazarlama Stratejileri: AB ve Türk Turizmi, Elektronik Sosyal Bilimler Dergisi, 8 (27).

Kotler, P. (2003a). A Framework For Marketing Management. (2nd Edition). New Jersey: Prentice Hall.

Kotler, P. (2003b). Kotler ve Pazarlama, Sistem yayıncılık, 3. bask1, İstanbul.

Levinson, J. C., Rubin, C. (1996). Guerrilla MarketingOn Line Weapons. New York: Houghton Mifflin Company.

Memişoğlu, A. (2014). Gerilla Pazarlama Faaliyetlerine İlişkin Tüketici Görüs ve Değerlendirmelerinin Belirlenmesi: Örnek Bir Uygulama, Atılım Üniversitesi, Sosyal Bilimler Enstitüsü, Yüksek Lisans Tezi.

Mugna, F. (2009). The 80 Best Guerrila Marketing Ideas I Have Ever Seen, https://blogof.francescomugnai.com/2009/11/th e-80-best-guerrilla-marketing-ideas-ive-everseen

Nufer, G. ve Bender, M. (2008). Guerilla Marketing, Reutlinger Diskussionsbeiträge zu Marketing \& Management, Reutlingen Üniversitesi, Almanya.

Özgül, N.(2008). Bütünleşik Pazarlama İletişiminde Gerilla Pazarlama Stratejilerinin Kullanılması. Yayımlanmamış Yüksek Lisans Tezi. Ege Üniversitesi Sosyal Bilimler Enstitüsü, İzmir.

Öztürk, H., Babacan, E. (2012). Bir Ölçek Geliştirme Çalışması: Hastanede Çalışan Sağlık Personeli İçin İş Güvenliği Ölçeği, Hemşirelikte Eğitim ve Araştırma Dergisi 2012; 9 (1): 36-42.

Pazarlama Makaleleri (2017). http://www.pazarlama makaleleri.com 
Pazarlamac1 Blog (2017), http://pazarlamaci.blogspot. com.tr

Pirtini, S., Şahin, Ş., Temelli P. (2007). Stratejik Yaratıcılık Açısından Gerilla Pazarlama ve Müşteri Deneyimi Yaratan Stratejiler, Pİ Pazarlama ve İletişim Kültürü Dergisi, Güz, (2007/3), s.4-13

Reşber, Z. (2013). Gerilla Pazarlamanın Temel Unsurlarından Gerilla Reklamcillk ve Göstergebilim Reklam İlişkisi: Türkiye'deki Gerilla Reklamcılık Uygulamalarının Göstergebilimsel Açıdan İncelenmesi. Yayımlanmamış Yüksek Lisans Tezi. Selçuk Üniversitesi Sosyal Bilimler Enstitüsü, Konya.

Schulte, T. (2007). "Was ist Guerilla Marketing? Große Wirkung mit kleinem Budget?", http://www.guerilla-marketing-portal.de/ (erişim tarihi: 29.01.2017).

Sharma S, (1996). Applied Multivariate Techniques, John Wiley Sonc Inc, New York, 116.

Sipahi B, Yurtkoru ES, Cinko M. (2008). Sosyal bilimlerde SPSS ile veri analizi. İstanbul: Beta Basım Yayım Dağıtım A.Ş.

Tek, Ö. B. (1997). Pazarlama İlkeleri. (7. Basım). İzmir: Cem Ofset. http://www.pazarlamamakaleleri. com/category/gerilla-pazarlama/ Erişim Tarihi: 29/01/20017

Y1ldı, Salih (2016). Effects Of Guerrilla Marketing On Brand Awareness and Consumers' Purchase Intention, 2. Uluslararas1 Osmaneli Sosyal Bilimler Kongresi, 12-14 Ekim 2016, ss.825834, Bilecik. 